ISSN 1392-3196 / e-ISSN 2335-8947

Zemdirbyste-Agriculture, vol. 101, No. 2 (2014), p. 139-146

DOI 10.13080/z-a.2014.101.018

\title{
Changes in enzyme activities as affected by green-manure catch crops and mineral nitrogen fertilization
}

\author{
Anna PIOTROWSKA-DŁUGOSZ, Edward WILCZEWSKI \\ University of Technology and Life Sciences \\ Bernardyńska 6, 85-029 Bydgoszcz, Poland \\ E-mail: apiotr@utp.edu.pl
}

\begin{abstract}
The estimation of soil microbial activity has been an important research issue because of the significant role that microorganisms play in nutrient cycling in soil. In a 3-year (August 2005 - August 2008) experiment, the effect of catch crops: oilseed radish (Raphanus sativus var. olifera L.) and field pea (Pisum sativum L.) vs. plots without a catch crop, and inorganic nitrogen $(\mathrm{N})$ fertilization at $0,40,80,120,160 \mathrm{~kg} \mathrm{ha}^{-1}$ year $^{-1}$ on soil dehydrogenase (DH), catalase (CAT) and fluorescein diacetate hydrolysis (FDAH) activities were investigated on albic, cutanic Luvisols ( $L V a b, L V c t$ ). The catch crops were sown at the beginning of August and ploughed in autumn in 2005, 2006 and 2007. Then the main crop, spring wheat (Triticum aestivum L.), was grown in 2006, 2007 and 2008. Soil samples were taken twice a year, before spring wheat sowing (March or April) and after harvesting (August). Generally, catch crops significantly influenced DH and CAT activities in all of the years of the investigation, while FDAH activity was affected only in 2007. There were higher DH and FDAH activities in catch crop treatment versus the control and only in some cases in field pea than in oilseed radish when both catch crops treatments were compared. DH and CAT activities were always higher in August than in March or April. Nitrogen fertilization influenced DH and FDAH activities only in 2007, while CAT activity was influenced during the entire experimental period (20062008). Generally, the highest CAT activity was noted at $\mathrm{N}$ rates of 80 or $120 \mathrm{~kg} \mathrm{ha}^{-1}$ year ${ }^{-1}$. Chemical properties (organic carbon, total nitrogen, $\mathrm{pH} 1 \mathrm{M} \mathrm{KCl}$ ) were not significantly affected by catch crops and inorganic $\mathrm{N}$ fertilization treatments. The studied indices of microbial biomass were significantly correlated with chemical soil properties.
\end{abstract}

Key words: catalase, dehydrogenase, fluorescein diacetate hydrolysis, green manure, Luvisol, mineral $\mathrm{N}$ fertilization.

\section{Introduction}

A significant decrease in the application of organic fertilizers has been observed due to the present economic circumstances of Poland, which has caused a decrease in the stock of farm animals (Statistical yearbook..., 2011). Many farmers have given up animal production and plants are now fertilized mostly with mineral fertilizers. Consequently, the depletion of soil organic matter and a decrease in soil fertility has occurred. Another consequence of the low animal stock is the small area planted with fodder plants and the domination of cereals and oilseed rape in the crop rotation, which have a low coefficient of soil organic matter reproduction. One of the management practices aimed at limiting the worsening of soil properties in simplified crop rotation is catch crops treatment and the use of their biomass as green manure. The benefits of crop rotation and green manuring in maintaining soil organic matter level have been established (Constantin et al., 2010). Some researchers have studied the influence of catch crops cultivated for green manure on soil biological properties (Kosteckas, Marcinkevičienè, 2009; Arlauskienè, Maikštènienè, 2010). A rapid increase in soil microorganisms content and activity occurs after a green manure crop is incorporated in the soil thereby increasing soil biological activity (Melero et al., 2006). Although a large number of researchers have examined how nitrogen affects microbial biomass content and activity (e.g., Treseder, 2008; Ramirez et al., 2010), we still know very little about how different sources and forms of $\mathrm{N}$ may impact microbial biomass, since contradictory results have been obtained. Adding $\mathrm{N}$ to soil can affect microbial activity directly by increasing $\mathrm{N}$ availability or as a result of indirect effects of the fertilizer inputs on other soil chemical properties (e.g., changes in $\mathrm{pH}$ or concentration of ions other than N) (Treseder, 2008). The positive or negative effect of fertilization on microbial biomass depends on many factors such as the composition of the microbial community, soil type and fertility, soil physicochemical properties, the form and the rate of the fertilizer and the time it is applied.

The microbial biomass is considered to be an important and labile fraction of soil organic matter that is involved in energy and nutrient cycling ( $\mathrm{Li}$ et al., 2009). Soil biota size and activity are directly related to the amount and quality of carbon and other nutrients that are available from plant residues and organic 
amendments (Okur et al., 2008). Some criteria for estimating overall microbial activity in soil have been proposed. Direct cell counting, soil microbial biomass carbon and nitrogen content, dehydrogenase and catalase activity, soil respiration, fluorescein diacetate hydrolysis activity and adenosine triphosphate content have become those studied most often (Benedetti, Dilly, 2006; Green et al., 2006). Dehydrogenase and catalase are intracellular enzymes that are involved in the microbial, oxidoreductase metabolism (Gianfreda, Ruggiero, 2006). Dehydrogenase activity (EC 1.1.) is known to oxidize soil organic matter by transferring protons and electrons from substrates to acceptors. Since dehydrogenase activity reflects the total range of oxidative activity of soil microflora, it can be used as a good indicator of total microbiological activity (Kızılkaya, Hepşen, 2007). Catalase (hydrogen-peroxide oxidoreductase, EC 1.11.1.6.) is found mainly in all aerobic bacteria and most facultative anaerobes, although it remains active outside of a cell due to its association with organic matter and/ or sorption on clay minerals (Nannipieri et al., 2002). Catalase activity is considered to be an indicator of aerobic microbial activity and soil fertility (Włodarczyk et al., 2001). The soil global hydrolase activity is evaluated by measuring the hydrolysis rate of fluorescein diacetate hydrolysis (FDAH). This method is considered to be a suitable index of the overall enzyme and microbial activity in soil because the hydrolysis of FDA is carried out by active cells with a variety of enzymes, including proteases, lipases and esterases (Green et al., 2006). It has been stated that the properties related to microbial biomass size and activity are more dynamic and respond more quickly to changes in crop management practices or environmental conditions than do properties such as total soil organic matter. Therefore, they are often used as sensitive indicators of organic matter turnover (Tejada et al., 2008).

The aim of the study was to assess the influence of catch crops grown for green manure and increasing mineral $\mathrm{N}$ fertilization rates on the activity of the soil microbial biomass measured by DH, CAT and FDAH activities. We hypothesized that: 1) biochemical variables related to microbial activity such as DH, CAT and FDAH activities would be improved by field pea (Pisum sativum L.) and oilseed radish (Raphanus sativus var. olifera L.) grown as catch crops, compared to the control, 2) the activities of the DH, CAT and FDAH would increase with increasing rates of $\mathrm{N}$ fertilization and 3) significant relationships between the studied enzymes and chemical properties of soil could be expected.

\section{Material and methods}

Site description and experimental design. The effect of catch crops and inorganic nitrogen $(\mathrm{N})$ fertilization treatments on soil biological activity indices was investigated in a 3-year (2005-2008) experiment. The two-factor, split-plot design experiment with four replications was carried out at the Experimental Station in Mochełek near Bydgoszcz, Midwestern Poland. The soil of the field experiment was albic, cutanic Luvisols $(L V a b, L V c t)$, that have the following pattern: Ap-EetBt-C (IUSS Working Group WRB, 2007), with a fine sandy loam texture (clay $5 \%$, sand $70 \%$, silt $23 \%$ ). The first factor was the $\mathrm{N}$ fertilization with $\mathrm{NH}_{4} \mathrm{NO}_{3}$ that was applied before and during the spring wheat growth period: the control (without $\mathrm{N}$ fertilization), $40 \mathrm{~kg} \mathrm{ha}^{-1}$ $\mathrm{N}$ (before sowing), $80 \mathrm{~kg} \mathrm{ha}^{-1} \mathrm{~N}$ (40 kg before sowing and $40 \mathrm{~kg}$ in the phase of the $1-2$ nodes), $120 \mathrm{~kg} \mathrm{ha}^{-1} \mathrm{~N}$ (60 kg before sowing and $60 \mathrm{~kg}$ in the phase of the 1-2 nodes), $160 \mathrm{~kg} \mathrm{ha}^{-1} \mathrm{~N}$ (60 kg before sowing, $60 \mathrm{~kg}$ in the phase of the 1-2 nodes and $40 \mathrm{~kg}$ before heading). The following catch crops treatment: field pea (Pisum sativum L.), oilseed radish (Raphanus sativus var. olifera L.), and the control without a catch crop was the second factor. The forecrop for plants grown as catch crops was spring barley (Hordeum vulgare L.). After the harvesting of spring barley, the straw was removed from the field and the soil was ploughed. Before the catch crops were sown the soil was cultivated using a cultivator with a roller. Catch crops were sown within the period of 3-11 of August in 2005-2007. No fertilization was applied before and during catch crops growing. The catch crops were harvested at the beginning of October and November every year (2005-2007). After harvesting, the green biomass of catch crops was chopped, spread on the soil surface and ploughed in. Spring wheat (Triticum aestivum L.) was sown between $30^{\text {th }}$ of March and $11^{\text {th }}$ of April of the following years (2006-2008) in the fields with incorporated catch crops biomass as well as in the control fields. Nitrogen fertilization was applied according to the experimental design. Moreover, phosphorus and potassium were broadcast before spring wheat sowing at the doses of $28.4 \mathrm{~kg} \mathrm{ha}^{-1} \mathrm{P}$ (as $\left.\left(\mathrm{NH}_{4}\right)_{3} \mathrm{PO}_{4}\right)$ and $74.7 \mathrm{~kg} \mathrm{ha}^{-1}$ $\mathrm{K}$ (as $\mathrm{KCl}, 60 \%$ of $\mathrm{K}$ ) and mixed with soil by means of a cultivator with a crumbler roller. Soil samples were collected twice a year, before spring wheat sowing (at the beginning of April in 2006 and at the end of March in 2007 and 2008) and after spring wheat harvesting (August 2006-2008). Soil samples were collected from a depth of 0-30 cm with an Egner's sampling stick. On each plot, 10 samples were collected randomly and bulked to provide one representative sample per plot. The site is characterized by a moderate climate with an average annual temperature over the study period of about $8.6^{\circ} \mathrm{C}$ and an average annual rainfall of $527 \mathrm{~mm}$.

Analysis of soil properties. Dehydrogenase(DH) was determined according to Thalmann (1968) after soil incubation with 2,3,5-triphenyl-tetrazolium chloride and a measurement of triphenylformazan (TPF) absorbance at $546 \mathrm{~nm}$ and was expressed as mg of TPF $\mathrm{kg}^{-1} 24 \mathrm{~h}^{-1}$. Catalase (CAT) activity was measured by manganometric titration of the surplus of $\mathrm{H}_{2} \mathrm{O}_{2}$ under acidic conditions according to the procedure of Johnson and Temple (1964). The CAT activity was expressed as mg $\mathrm{H}_{2} \mathrm{O}_{2}$ $\mathrm{g}^{-1} \mathrm{~h}^{-1}$. Total soil hydrolytic activity was evaluated by measuring the activity of fluorescein diacetate hydrolysis (FDAH) as described by Adam and Duncan (2001). One unit of FDAH activity was defined as $\mathrm{mg}$ of fluorescein (F) produced at $37^{\circ} \mathrm{C}$ for 1 hour by $1 \mathrm{~kg}$ of dried soil $\left(\mathrm{mg} \mathrm{F} \mathrm{kg}^{-1} \mathrm{~h}^{-1}\right)$. The microbial activity assays were performed with field-moist soil and calculated on the basis of the oven-dry $\left(105^{\circ} \mathrm{C}\right)$ soil weight. Triplicates were performed for each activity assay. Total nitrogen $\left(\mathrm{N}_{\text {tot }}\right)$ in the soil was determined by the Kjeldahl method. Soil organic carbon $\left(\mathrm{C}_{\text {org }}\right)$ content was determined using the dichromate oxidation procedure, while soil $\mathrm{pH}(1 \mathrm{M}$ $\mathrm{KCl})$ was measured using the potentiometric method in 1:2.5 soil:solution suspensions. 
Statistical analysis. An ANOVA test was performed on the results and analyses were carried out using Statistica 8.1 for Windows software. All studied properties data follow normal distribution according to the Shapiro-Wilk test. A two-way analysis of variance was performed to examine the main effect of $\mathrm{N}$ fertilization rates and the type of catch crop on the studied enzyme activities. The first factor ( $\mathrm{N}$ fertilization) was applied at five levels, while the second factor (catch crops) was given in three levels. When significant treatment effects were found, Tukey's test was used to compare treatment means. Means were considered significantly different at $P<0.05$. Relations between the enzymatic activity and the chemical parameters were estimated by correlation analysis based on Pearson's correlation coefficients $(P<0.05)$

\section{Results and discussion}

Chemical properties. Generally, neither catch crop nor $\mathrm{N}$ fertilization treatments influenced chemical properties (total nitrogen, organic carbon, $\mathrm{pH}_{\mathrm{KCl}}$ ) significantly $(P<0.05)$. That is why we did not present the data in a table. Total $\mathrm{N}$ content ranged from 0.63 to $0.75 \mathrm{~g} \mathrm{~kg}^{-1}$, with a mean value of $0.68 \mathrm{~g} \mathrm{~kg}^{-1}$, while $\mathrm{C}_{\text {org }}$ ranged from 6.28 to $8.0 \mathrm{~g} \mathrm{~kg}^{-1}$, with a mean value of $7.07 \mathrm{~g}$ $\mathrm{kg}^{-1}$ (mean values of the period 2006-2008). The average $\mathrm{pH}_{\mathrm{KCl}}$ in 2006 was 6.7 in March and 6.3 in August, while in 2007 and $2008 \mathrm{pH}_{\mathrm{KCl}}$ values were similar in spring and summer samples, and the mean values were 6.1 and 5.5, respectively.

Temporal changes of studied enzymes. The properties studied displayed clear temporal changes. All of the studied parameters were generally higher in the summer samples as compared to the spring samples for each of the catch crop treatments (Tables 1-3). They also differed significantly in each year of the study (2006-2008) (FDAH data presented only for 2007). The seasonal changes can be explained by the enhanced rhizosphere microbial population that accompanies the rapid development of the crop root system during the growing period (Weisskopf et al., 2008). The release of nutrients into the soil from decaying organic matter with a high contribution of catch crops biomass would increase microbial activity even further and could account for the continuing increase in enzymatic activity (RodríguezKábana, Truelove, 1982). Moreover, it is commonly known that weather conditions, especially rainfall and temperature, have a great impact on soil biological properties (Niu et al., 2012). All of the properties studied showed a higher activity in August when the temperature was higher than in March or April. However, we did not find any marked interaction between the rainfall level and microbial biomass data in the subsequent years of the experiment (data not presented).

Table 1. Dehydrogenase (DH) activity (mg TPF $\mathrm{kg}^{-1} 24 \mathrm{~h}^{-1}$ ) as influenced by the catch crop and $\mathrm{N}$ fertilization $\left(\mathrm{kg} \mathrm{ha}^{-1}\right)$ treatments

\begin{tabular}{|c|c|c|c|c|c|c|}
\hline \multirow{2}{*}{ Year } & \multirow{2}{*}{ Month } & \multirow{2}{*}{$\begin{array}{l}\mathrm{N} \text { fertilization } \\
\left(1^{\text {st }} \text { factor }\right)\end{array}$} & \multicolumn{3}{|c|}{ Catch crop ( $2^{\text {nd }}$ factor $)$} & \multirow[b]{2}{*}{ mean } \\
\hline & & & field pea & oilseed radish & control & \\
\hline \multirow{7}{*}{2006} & March & & $5.2 \mathrm{a}$ & $5.0 \mathrm{a}$ & $5.1 \mathrm{a}$ & 5.1 \\
\hline & \multirow{6}{*}{ August } & 0 & $7.8 \mathrm{aA}$ & $7.5 \mathrm{aA}$ & $7.2 \mathrm{aA}$ & $7.5 \mathrm{~A}$ \\
\hline & & 40 & $8.5 \mathrm{aA}$ & $8.1 \mathrm{aA}$ & $7.2 \mathrm{aA}$ & $7.9 \mathrm{~A}$ \\
\hline & & 80 & $9.1 \mathrm{aA}$ & $8.4 \mathrm{aA}$ & $9.2 \mathrm{aA}$ & $8.9 \mathrm{~A}$ \\
\hline & & 120 & $9.9 \mathrm{aA}$ & $8.6 \mathrm{abA}$ & $7.4 \mathrm{bA}$ & $8.6 \mathrm{~A}$ \\
\hline & & 160 & $10.2 \mathrm{aA}$ & $9.1 \mathrm{abA}$ & $7.3 \mathrm{bA}$ & $8.9 \mathrm{~A}$ \\
\hline & & mean & $9.1 \mathrm{a}$ & $8.3 \mathrm{ab}$ & $7.7 \mathrm{~b}$ & 8.4 \\
\hline \multirow{7}{*}{2007} & March & & $20.1 \mathrm{a}$ & $12.1 \mathrm{~b}$ & $10.3 \mathrm{~b}$ & 14.2 \\
\hline & \multirow{6}{*}{ August } & 0 & $28.7 \mathrm{bAB}$ & $43.0 \mathrm{aA}$ & $16.5 \mathrm{cA}$ & $29.4 \mathrm{~A}$ \\
\hline & & 40 & $38.5 \mathrm{aA}$ & $33.7 \mathrm{aAB}$ & $16.8 \mathrm{bA}$ & $29.7 \mathrm{~A}$ \\
\hline & & 80 & $30.0 \mathrm{aAB}$ & $32.5 \mathrm{aAB}$ & $22.6 \mathrm{bA}$ & $28.4 \mathrm{~A}$ \\
\hline & & 120 & $26.7 \mathrm{aAB}$ & $20.0 \mathrm{bBC}$ & $18.2 \mathrm{bA}$ & $21.6 \mathrm{~B}$ \\
\hline & & 160 & $23.0 \mathrm{aB}$ & $22.8 \mathrm{aB}$ & $14.0 \mathrm{bA}$ & $19.9 \mathrm{~B}$ \\
\hline & & mean & $29.4 \mathrm{a}$ & $30.4 \mathrm{a}$ & $17.6 \mathrm{~b}$ & 25.8 \\
\hline \multirow{7}{*}{2008} & March & & $30.7 \mathrm{a}$ & $27.5 \mathrm{ab}$ & $23.5 \mathrm{~b}$ & 27.2 \\
\hline & \multirow{6}{*}{ August } & 0 & $40.0 \mathrm{aA}$ & $38.3 \mathrm{aA}$ & $28.7 \mathrm{bA}$ & $35.7 \mathrm{~A}$ \\
\hline & & 40 & $42.9 \mathrm{aA}$ & $40.2 \mathrm{aA}$ & $33.9 \mathrm{bA}$ & $39.0 \mathrm{~A}$ \\
\hline & & 80 & $50.4 \mathrm{aA}$ & $43.4 \mathrm{abA}$ & $39.4 \mathrm{bA}$ & $44.4 \mathrm{~A}$ \\
\hline & & 120 & $37.7 \mathrm{aA}$ & $34.2 \mathrm{abA}$ & $29.2 \mathrm{bA}$ & $33.7 \mathrm{~A}$ \\
\hline & & 160 & $32.3 \mathrm{aA}$ & $34.2 \mathrm{aA}$ & $28.4 \mathrm{aA}$ & $31.6 \mathrm{~A}$ \\
\hline & & mean & $40.7 \mathrm{a}$ & $38.1 \mathrm{a}$ & $31.9 \mathrm{~b}$ & 36.9 \\
\hline
\end{tabular}

Notes. TPF - triphenylformazan. Lowercase letters indicate comparison among catch crops treatment (within the same $\mathrm{N}$ fertilization rate in August); values followed by the same lowercase letters within each row do not differ significantly at $P<0.05$. Uppercase letters indicate comparison among $\mathrm{N}$ fertilization rates within the same catch crop; values followed by the same uppercase letters within each column do not differ significantly at $P<0.05$.

The influence of catch crops and $N$ fertilization on thestudied enzymes. Theresults showed thatcatch crops applied as green manure and $\mathrm{N}$ fertilization may greatly alter soil microbial biomass activity as measured by $\mathrm{DH}$ and CAT activities (Tables 1-2 and 4-5). Incorporation of catch crops did not affect DH activity in March 2006 compared to the control. There was a significantly higher DH activity in March 2007 in field pea as compared to 
oilseed radish and control (Table 1). In the last year of the investigation (March 2008), DH activity in field pea was significantly higher than in the control. In August 2006, the soil DH activity was significantly affected by catch crops treatment with 120 and $160 \mathrm{~kg} \mathrm{ha}^{-1}$ year-1 $^{-1} \mathrm{~N}$ only. In 2007 and 2008, DH activity was usually significantly higher in both catch crops treatments than in the control, except for the soil fertilized with $160 \mathrm{~kg} \mathrm{ha}^{-1}$ year $^{-1} \mathrm{~N}$ in
2008 (Table 1). DH activity appeared to be more sensitive to the catch crops treatment studied here than the FDAH activity, probably due to its being associated with a viable microbial population (Nannipieri et al., 2002). The results of our study confirm that the microbial biomass was more active in the plots with catch crops, mainly because of the contribution of plant residues incorporated into the soil.

Table 2. Catalase (CAT) activity $\left(\mathrm{mg} \mathrm{H}_{2} \mathrm{O}_{2} \mathrm{~g}^{-1} \mathrm{~h}^{-1}\right)$ as influenced by the catch crop and $\mathrm{N}$ fertilization $\left(\mathrm{kg} \mathrm{ha}^{-1}\right)$ treatments

\begin{tabular}{|c|c|c|c|c|c|c|}
\hline \multirow{2}{*}{ Year } & \multirow{2}{*}{ Month } & \multirow{2}{*}{$\begin{array}{l}\mathrm{N} \text { fertilization } \\
\left(1^{\text {st }} \text { factor }\right)\end{array}$} & \multicolumn{3}{|c|}{ Catch crop ( $2^{\text {nd }}$ factor $)$} & \multirow[b]{2}{*}{ mean } \\
\hline & & & field pea & oilseed radish & control & \\
\hline \multirow{7}{*}{2006} & March & & $15.4 \mathrm{a}$ & $16.6 \mathrm{a}$ & $15.7 \mathrm{a}$ & 15.9 \\
\hline & \multirow{6}{*}{ August } & 0 & $21.5 \mathrm{aB}$ & $18.4 \mathrm{bC}$ & $20.6 \mathrm{aA}$ & $20.2 \mathrm{~A}$ \\
\hline & & 40 & $23.4 \mathrm{aB}$ & $21.5 \mathrm{bB}$ & $21.3 \mathrm{bA}$ & $22.1 \mathrm{~A}$ \\
\hline & & 80 & $26.3 \mathrm{aA}$ & $24.3 \mathrm{bA}$ & $22.3 \mathrm{cA}$ & $24.3 \mathrm{~A}$ \\
\hline & & 120 & $23.6 \mathrm{aB}$ & $21.1 \mathrm{bB}$ & $21.5 \mathrm{bA}$ & $22.1 \mathrm{~A}$ \\
\hline & & 160 & $23.8 \mathrm{aB}$ & $21.5 \mathrm{bB}$ & $21.1 \mathrm{bA}$ & $22.1 \mathrm{~A}$ \\
\hline & & mean & $23.7 \mathrm{a}$ & $21.4 \mathrm{~b}$ & $21.4 \mathrm{~b}$ & 22.2 \\
\hline \multirow{7}{*}{2007} & March & & $21.2 \mathrm{ab}$ & $22.2 \mathrm{a}$ & $20.5 \mathrm{~b}$ & 21.3 \\
\hline & \multirow{6}{*}{ August } & 0 & $28.9 \mathrm{aC}$ & $24.5 \mathrm{bC}$ & $22.9 \mathrm{bC}$ & $25.4 \mathrm{C}$ \\
\hline & & 40 & $31.9 \mathrm{aB}$ & $27.7 \mathrm{bB}$ & $25.2 \mathrm{cB}$ & $28.3 \mathrm{~A}$ \\
\hline & & 80 & $34.2 \mathrm{aA}$ & $28.9 \mathrm{bA}$ & $25.8 \mathrm{cB}$ & $29.6 \mathrm{~A}$ \\
\hline & & 120 & $31.6 \mathrm{aB}$ & $29.6 \mathrm{bA}$ & $27.3 \mathrm{cA}$ & $29.5 \mathrm{~A}$ \\
\hline & & 160 & $28.3 \mathrm{aC}$ & $24.2 \mathrm{bC}$ & $25.8 \mathrm{bB}$ & $26.1 \mathrm{~B}$ \\
\hline & & mean & $31.0 \mathrm{a}$ & $27.0 \mathrm{~b}$ & $25.4 \mathrm{~b}$ & 27.8 \\
\hline \multirow{7}{*}{2008} & March & & $27.3 \mathrm{a}$ & $25.0 \mathrm{a}$ & $24.0 \mathrm{a}$ & 25.9 \\
\hline & \multirow{6}{*}{ August } & 0 & $32.6 \mathrm{aC}$ & $27.7 \mathrm{bC}$ & $24.3 \mathrm{cB}$ & $28.2 \mathrm{C}$ \\
\hline & & 40 & $35.3 \mathrm{aBC}$ & $31.8 \mathrm{bAB}$ & $30.6 \mathrm{bA}$ & $32.6 \mathrm{~B}$ \\
\hline & & 80 & $40.7 \mathrm{aA}$ & $43.6 \mathrm{bA}$ & $32.4 \mathrm{cA}$ & $38.9 \mathrm{~A}$ \\
\hline & & 120 & $37.1 \mathrm{aA}$ & $34.4 \mathrm{bA}$ & $31.5 \mathrm{cA}$ & $34.3 \mathrm{~A}$ \\
\hline & & 160 & $32.0 \mathrm{aC}$ & $30.6 \mathrm{abBC}$ & $28.9 \mathrm{bA}$ & $30.5 \mathrm{BC}$ \\
\hline & & mean & $35.5 \mathrm{a}$ & $33.6 \mathrm{a}$ & $29.5 \mathrm{~b}$ & 32.9 \\
\hline
\end{tabular}

Explanations under Table 1

Table 3. Fluorescein diacetate hydrolysis (FDAH) activity $\left(\mathrm{mg} \mathrm{F} \mathrm{kg}^{-1} \mathrm{~h}^{-1}\right)$ as influenced by the catch crop and $\mathrm{N}$ fertilization $\left(\mathrm{kg} \mathrm{ha}^{-1}\right)$ treatments

\begin{tabular}{|c|c|c|c|c|c|c|}
\hline \multirow{2}{*}{ Year } & \multirow{2}{*}{ Month } & \multirow{2}{*}{$\begin{array}{l}\mathrm{N} \text { fertilization } \\
\left(1^{\text {st }} \text { factor }\right)\end{array}$} & \multicolumn{3}{|c|}{ Catch crop ( $2^{\text {nd }}$ factor $)$} & \multirow[b]{2}{*}{ mean } \\
\hline & & & field pea & oilseed radish & control & \\
\hline \multirow{7}{*}{2007} & March & & $23.5 \mathrm{a}$ & $25.2 \mathrm{a}$ & $29.2 \mathrm{a}$ & 26.0 \\
\hline & \multirow{6}{*}{ August } & 0 & $27.7 \mathrm{aAB}$ & $27.9 \mathrm{aB}$ & $24.0 \mathrm{bB}$ & $26.5 \mathrm{~B}$ \\
\hline & & 40 & $32.5 \mathrm{aA}$ & $31.3 \mathrm{abA}$ & $28.6 \mathrm{bAB}$ & $30.8 \mathrm{AB}$ \\
\hline & & 80 & $35.1 \mathrm{aA}$ & $34.2 \mathrm{aA}$ & $32.7 \mathrm{aA}$ & $34.0 \mathrm{~A}$ \\
\hline & & 120 & $31.0 \mathrm{aA}$ & $30.3 \mathrm{abAB}$ & $27.2 \mathrm{bAB}$ & $29.5 \mathrm{~B}$ \\
\hline & & 160 & $23.8 \mathrm{aB}$ & $27.1 \mathrm{aB}$ & $23.9 \mathrm{aB}$ & $24.9 \mathrm{~B}$ \\
\hline & & mean & $30.0 \mathrm{a}$ & $30.2 \mathrm{a}$ & $27.3 \mathrm{~b}$ & 29.2 \\
\hline
\end{tabular}

Explanations under Table 1

Table 4. Statistical differences ( $F$-values and significance level) between means of variables by one-way $A N O V A$ with factor catch crops (d.f. $=2)$

\begin{tabular}{cccc}
\hline \multirow{2}{*}{ Enzymes } & \multicolumn{3}{c}{ Years (March) } \\
\cline { 2 - 4 } & 2006 & 2007 & 2008 \\
\hline Dehydrogenase & 0.166 n.s. & $7.995^{*}$ & 1.423 n.s. \\
Calatase & 1.214 n.s. & $5.542 *$ & 2.093 n.s. \\
$\begin{array}{c}\text { Fluorescein diacetate } \\
\text { hydrolysis }\end{array}$ & 1.386 n.s. & 1.723 n.s. & 0.483 n.s. \\
\hline \begin{tabular}{c} 
d.f. - degree of freedom, n.s. - not significant; $*-P<0.05$ \\
\hline
\end{tabular}
\end{tabular}

Generally, the fertilization treatment had a weaker impact on DH compared to the catch crops (Tables 1 and 5). The activity was affected only in the plots with field pea and oilseed radish catch crops in 2007. The results of some authors suggest that DH activity is sensitive to the activatory and/or inhibitory effects associated with an increasing amount of applied $\mathrm{N}$ fertilizers (Goyal et al., 1992; Klikocka et al., 2012), which is in disagreement with our results, which showed that DH was poorly influenced by mineral $\mathrm{N}$ fertilization rates. In other studies, the DH activity was also poorly influenced by mineral $\mathrm{N}$ fertilization. Thus, in two different regimes of organic manuring on a sandy arable soil (Kautz et al., 
Table 5. Statistical differences ( $F$-values and significance level) between means of variables by two-way $A N O V A$ with factors catch crops and N fertilization rates (August 2006-2008)

\begin{tabular}{|c|c|c|c|c|}
\hline Enzymes & Year & $\begin{array}{l}\mathrm{N} \text { fertilization } \\
(\text { d.f. }=4)\end{array}$ & $\begin{array}{l}\text { Catch crops } \\
(\text { d.f. }=2)\end{array}$ & $\begin{array}{c}\text { Interactions: } \\
\text { catch crops } \times \mathrm{N} \text { fertilization } \\
(\text { d.f. }=8)\end{array}$ \\
\hline \multirow{3}{*}{ Dehydrogenase } & 2006 & 3.571 n.s. & $5.157^{*}$ & 1.116 n.s. \\
\hline & 2007 & $7.684 * *$ & $31.669 * * *$ & $3.988 * *$ \\
\hline & 2008 & 3.130 n.s. & $4.110 *$ & 0.164 n.s. \\
\hline \multirow{3}{*}{ Calatase } & 2006 & $9.388 * *$ & $16.554 * * *$ & 1.062 n.s. \\
\hline & 2007 & $33.789 * * *$ & $29.326 * * *$ & 1.199 n.s. \\
\hline & 2008 & $14.810^{* * *}$ & $28.694 * * *$ & 0.992 n.s. \\
\hline \multirow{3}{*}{$\begin{array}{c}\text { Fluorescein } \\
\text { diacetate hydrolysis }\end{array}$} & 2006 & 1.562 n.s. & 3.276 n.s. & 1.116 n.s. \\
\hline & 2007 & $60.000 * * *$ & $12.301 * * *$ & 1.071 n.s. \\
\hline & 2008 & 2.825 n.s. & 3.488 n.s. & 1.408 n.s. \\
\hline
\end{tabular}

d.f. - degree of freedom, n.s. - not significant; $*-P<0.05, * *-P<0.01, * * *-P<0.001$

2004) and in sandy loam under maize (Marinari et al., 2000), mineral $\mathrm{N}$ fertilizer had weaker effects on $\mathrm{DH}$ activity than organic manuring. According to Marinari et al. (2000), this might be due to the fact that mineral $\mathrm{N}$ additions are rapidly dispersed into the soil organic matter or are lost by leaching without affecting soil biological activity. As stated by Melero et al. (2006), no effect of different $\mathrm{N}$ fertilization rates $(0,50$ and $150 \mathrm{~kg} \mathrm{ha}^{-1}$ year $^{-1} \mathrm{~N}$ ) was found on DH activity. According to Goyal et al. (1992), the low response of DH activity to $\mathrm{N}$ doses may be due to the interference of nitrates, which serve as an alternate electron acceptor, resulting in low activities at higher rates of $\mathrm{N}$ fertilizer application. As a consequence, using DH activity as a microbial indicator in soil with high doses of $\mathrm{N}$ fertilizers is not recommended by some authors (Okur et al., 2008).

The lowest CAT activity was noted in 2006 and in the succeeding years the activity was higher (Table 2). In 2006 and 2007, higher CAT activity in August was found with the field pea catch crop, lower with the oilseed radish catch crop and in the control. In 2008, CAT activity in the control was significantly lower than after both catch crops. Soil CAT activity changed significantly as a function of $\mathrm{N}$ fertilization treatments and in the entire experiment period (2006-2008). Increasing rates from 0 to 80 or $120 \mathrm{~kg} \mathrm{ha}^{-1}$ year ${ }^{-1} \mathrm{~N}$ gradually increased the CAT activity in catch crop treatments. The highest CAT activity was noted at the rate of $80 \mathrm{~kg} \mathrm{ha}^{-1}$ year $^{-1} \mathrm{~N}$ in 2006, while in 2007 and 2008, it was recorded at a dose of $80-120 \mathrm{~kg} \mathrm{ha}^{-1}$ year $^{-1} \mathrm{~N}$. The highest $\mathrm{N}$ fertilization rate $\left(160 \mathrm{~kg} \mathrm{ha}^{-1}\right.$ year $\left.^{-1} \mathrm{~N}\right)$ decreased the CAT activity in all of the years and for both catch crops, compared to the lower (80-120 kg ha ${ }^{-1}$ year $\left.^{-1} \mathrm{~N}\right) \mathrm{N}$ fertilization rates. In the control, the influence of $\mathrm{N}$ fertilization on CAT activity in 2007 was similar to that after catch crops, while in 2006 this parameter was unaffected by $\mathrm{N}$ rates. As stated by Rodríguez-Kábana and Truelove (1982), the CAT activity was less sensitive to added $\mathrm{N}$ fertilization than to legume rotation components. The addition of inorganic $\mathrm{N}\left(67 \mathrm{~kg} \mathrm{ha}^{-1}\right)$ to the plots with winter legumes and $\mathrm{PK}$ fertilization resulted in a small but significant reduction in CAT activity. Furthermore, the same authors stated that the elimination of a winter legume from the otherwise complete (NPK) fertilization regime resulted in a drastic reduction in CAT activity. This suggested that the major component that influences CAT activity was the plant biomass incorporated into the soil and not the fertilization regime.

FDAH activity was significantly influenced by the rate of $\mathrm{N}$ fertilization and catch crops treatments only in August 2007 (Tables 3-5). The small variations in FDAH activity displayed in two of the three studied years were expected. This activity is, after all, a measure of the overall hydrolytic ability of a soil and as such, it reflects the positive and negative contributions due to the different hydrolytic enzyme activities (Piotrowska et al., 2006). Earlier Bandick and Dick (1999) reported that FDAH activity is relatively stable between seasons and averaged across the sampling period did not show any statistically significant differences. Similar data was found in this research, where the results obtained in March or April were almost at the same level as in August (data presented only for 2007). The highest FDAH activity in 2007 was noted with $40-120 \mathrm{~kg} \mathrm{ha}^{-1}$ year ${ }^{-1} \mathrm{~N}$ in plots with field pea and with $80 \mathrm{~kg} \mathrm{ha}^{-1}$ year ${ }^{-1} \mathrm{~N}$ in oilseed radish and the control. Significantly higher FDAH rates were obtained with field pea catch crops versus the control with the 0,40 and $120 \mathrm{~kg} \mathrm{ha}^{-1}$ year $^{-1} \mathrm{~N}$, while at rates of 80 and $160 \mathrm{~kg} \mathrm{ha}^{-1}$ year $^{-1} \mathrm{~N}$, there were no significant differences between field pea, oilseed radish and the control.

To summarize, the highest activity of the microbial properties studied was noted in the treatments where catch crops were applied as green manure together with moderate mineral $\mathrm{N}$ fertilization $\left(80-120 \mathrm{~kg} \mathrm{ha}^{-1}\right.$ year $^{-1} \mathrm{~N}$ ). Such conditions were also optimal for yielding of spring wheat (Wilczewski, 2013). This suggested the great significance of joint organic and mineral fertilization for optimal soil biological activity and consequently for better conditions for plant growth and yield. In fact, as stated by Shah et al. (2009), the application of combined mineral $(75 \%$ of manurial components mass) and organic ( $25 \%$ of manurial components mass) fertilization significantly increased the yield of wheat grain and straw compared to $100 \%$ of organic or mineral fertilizers applied separately. Microbial biomass is considered to be a better indicator of any of soil alteration than organic matter $\left(\mathrm{C}_{\text {org }}\right)$, as it responds to changes in soil management more 
rapidly and sensitively (Okur et al., 2008). In fact, both catch crop and $\mathrm{N}$ fertilization treatments, in contrast to microbial biomass activity indices, did not significantly influence $\mathrm{N}_{\text {tot }}$ and $\mathrm{C}_{\text {org }}$ concentrations in this experiment.
Correlation among the studied properties.

According to the linear regression analysis, the indices of soil biomass activity were significantly correlated with some chemical properties (Table 6).

Table 6. Correlation matrix between soil enzyme activities and chemical properties in experimental period (20062008)

\begin{tabular}{ccccc}
\hline Month & & $\mathrm{C}_{\text {org }}$ & $\mathrm{N}_{\text {tot }}$ & $\mathrm{pH}_{\mathrm{KCl}}$ \\
\hline \multirow{2}{*}{$\begin{array}{c}\text { March (April 2006) } \\
(\mathrm{n}=36)\end{array}$} & dehydrogenase calatase & - & - & 0.534 \\
& fluorescein & 0.566 & 0.356 & - \\
\hline August & diacetate hydrolysis & - & 0.555 & - \\
$(\mathrm{n}=90)$ & dehydrogenase calatase & 0.696 & 0.378 & 0.567 \\
& fluorescein & 0.756 & 0.324 & 0.458 \\
\hline
\end{tabular}

$\mathrm{C}_{\text {org }}$ - organic carbon, $\mathrm{N}_{\text {tot }}-$ total nitrogen; only coefficients significant at $P<0.05$ are presented

In March (April 2006) CAT activity was significantly correlated with $\mathrm{C}_{\text {org }}$ and $\mathrm{N}_{\text {tot }}$, while FDAH activity was significantly correlated with $\mathrm{N}_{\text {tot }}$ content $(P<0.05)$. All enzyme activities in August were
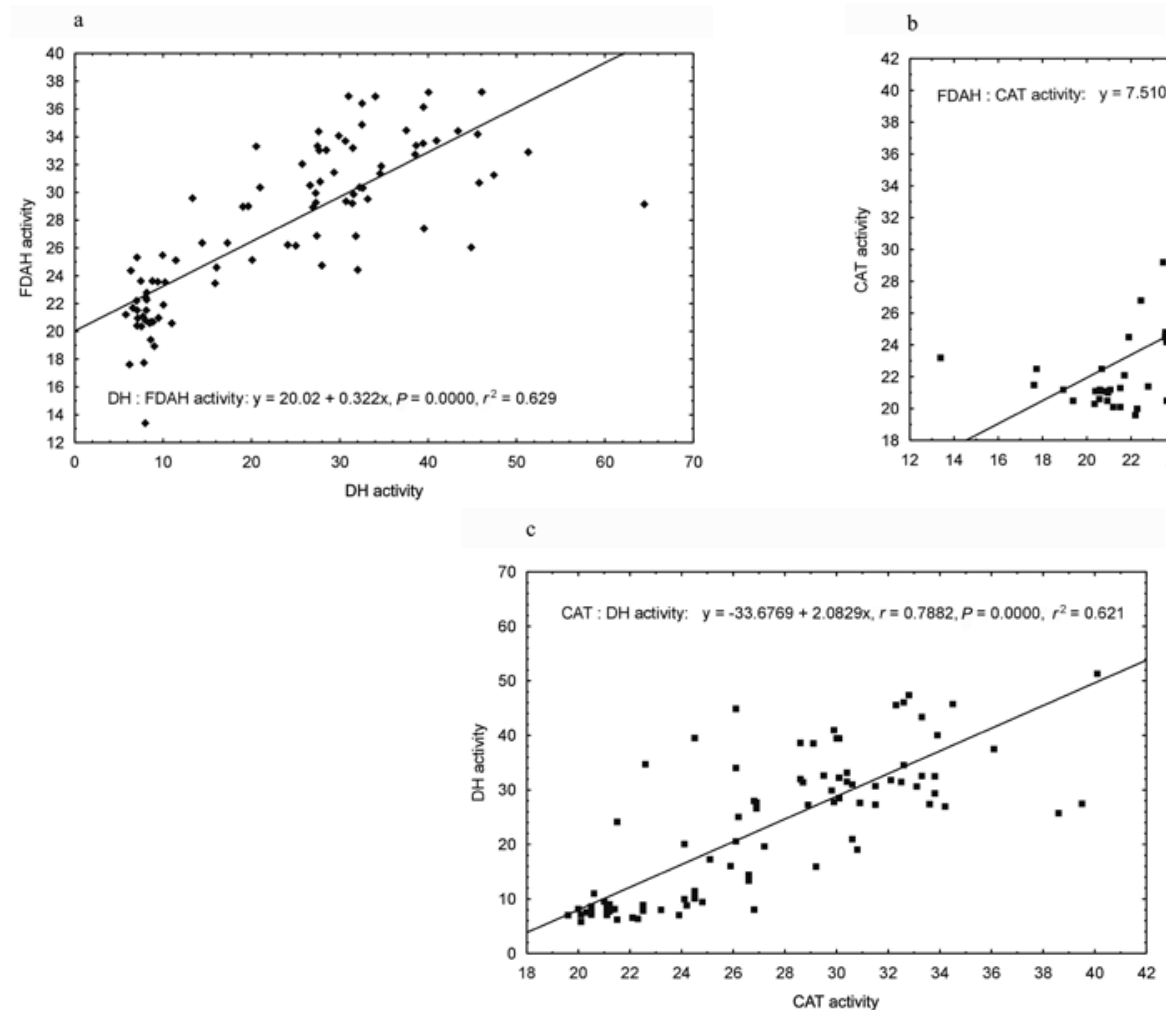

Figure. The relationship between dehydrogenase (DH) and fluorescein diacetate hydrolysis (FDAH) activities (A), FDAH and catalase (CAT) activities (B) and CAT and DH activities (C) (average values for August 2006-2008)

Soil $\mathrm{C}_{\mathrm{org}}$ and $\mathrm{N}$ are among the most important soil properties that may considerably influence the activities of soil enzymes since they reflect the level of organic matter (Gianfreda, Ruggiero, 2006). That is why soil enzyme activities are expected to be positively related to soil organic matter. Catch crops and $\mathrm{N}$ fertilization treatments can enhance soil microbial biomass content and activity by increasing the organic matter content in soil. The other expected correlations were those between $\mathrm{pH}_{\mathrm{KCl}}$ and microbial biomass activity since each enzyme shows a characteristic $\mathrm{pH}$-dependent activity profile, significantly correlated with $\mathrm{C}_{\mathrm{org}}, \mathrm{N}_{\text {tot }}$, and $\mathrm{pH}_{\mathrm{KCl}}$ values. In addition, the indices of soil microbial biomass activity were significantly and positively correlated with each other $\left(r^{2}=0.598-0.629\right)$ (Fig.).

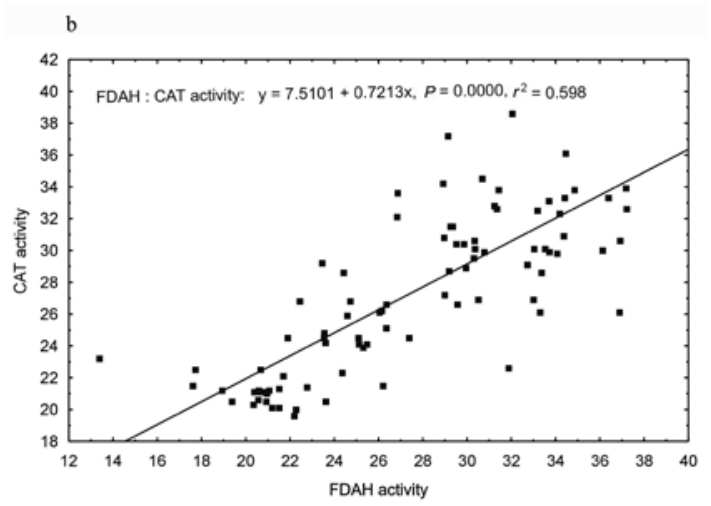

an optimum $\mathrm{pH}$ for its maximum activity and a specific stability, which is related to soil pH (Gianfreda, Ruggiero, 2006).

\section{Conclusions}

1. Catch crops grown for green manure significantly increased soil biological activity during the growing period of spring wheat within the three experimental years, whereas the impact of field pea appeared to be not much better than that of oilseed radish. Therefore, it can be concluded that the cultivation of both 
catch crops studied may be considered a good practice in helping to increase soil biological activity, which is a measure of soil fertility.

2. The catalase (CAT) activity was the only property clearly influenced by nitrogen $(\mathrm{N})$ fertilization, while dehydrogenase (DH) and fluorescein diacetate hydrolysis (FDAH) activities were changed significantly only in one of the three experimental years. Generally in the treatments with catch crops, the CAT activity increased significantly with increasing $\mathrm{N}$ fertilization rates up to 80 or $120 \mathrm{~kg} \mathrm{ha}^{-1}$ year $^{-1} \mathrm{~N}$ and then decreased markedly. We can therefore conclude that the combined effect of catch crops applied as green manure and moderate mineral $\mathrm{N}$ fertilization was better for soil microbial biomass activity than that of only green manure or $\mathrm{N}$ fertilization and that this can be recommended as a means of increasing soil biological activity.

3. As compared to FDAH, both oxidoreductase activities were more sensitive to the presence of catch crops, while only CAT activity reacted significantly to the $\mathrm{N}$ fertilization rates within the entire study period. That is why the DH and CAT activities appeared to be better indicators of the influence of the factors studied on soil biological activity compared to the FDAH activity.

\section{Acknowledgments}

The authors thank the University of Technology and Life Sciences in Bydgoszcz for supporting this work. Much gratitude is due to Michele Simmons for proofreading the article.

Received 22052013

Accepted 31102013

\section{References}

Adam G., Duncan H. 2001. Development of a sensitive and rapid method for the measurement of total microbial activity using fluorescein diacetate (FDA) in a range of soils. Soil Biology and Biochemistry, 33: 943-951 http://dx.doi.org/10.1016/S0038-0717(00)00244-3

Arlauskienè A., Maikštènienė S. 2010. The effect of cover crop and straw applied for manuring on spring barley yield and agrochemical soil properties. Zemdirbyste-Agriculture, 97 (2): 61-72

Bandick A. K., Dick R. P. 1999. Field management effects on soil enzyme activities. Soil Biology and Biochemistry, 31: 1471-1479

http://dx.doi.org/10.1016/S0038-0717(99)00051-6

Benedetti A., Dilly O. 2006. Approaches to defining, monitoring, evaluating and managing soil quality. Introduction. Bloem J. et al. (eds). Microbiological methods for assessing soil quality, p. 3-14

Constantin J., Mary B., Laurent F., Aubrion G., Fontaine A., Kerveillant P., Beaudoin N. 2010. Effects of catch crops, no till and reduced nitrogen fertilization on nitrogen leaching and balance in three long-term experiments. Agriculture, Ecosystems and Environment, 135 (4): 268-278 http://dx.doi.org/10.1016/j.agee.2009.10.005

Gianfreda L., Ruggiero P. 2006. Enzyme activities in soil. Nannipieri P., Smalla K. (eds). Nucleic acids and protein in soil, p. 257-311

Goyal S., Mishra M. M., Hooda I. S., Singh R. 1992. Organic matter microbial biomass relationship in field experiment under tropical conditions: effects of inorganic fertilization and organic amendments. Soil Biology and Biochemistry, 24: $1081-1084$

http://dx.doi.org/10.1016/0038-0717(92)90056-4

Green V. S., Stott D. E., Diack M. 2006. Assay for fluorescein diacetate hydrolytic activity: optimization for soil samples. Soil Biology and Biochemistry, 38: 693-701 http://dx.doi.org/10.1016/j.soilbio.2005.06.020

IUSS Working Group WRB. 2007. World Reference Base for Soil Resources 2006, first update 2007. World Soil Resources Reports No. 103. FAO, Rome

Johnson J. L., Temple K. L. 1964. Some variables affecting the measurement of "catalase activity" in soil. Soil Science Society of America Journal, 28 (2): 207-209 http://dx.doi. org/10.2136/sssaj1964.03615995002800020024x

Kautz T. Wirth S., Ellmer F. 2004. Microbial activity in a sandy arable soil is governed by the fertilization regime. European Journal of Soil Biology, 40: 87-94 http://dx.doi.org/10.1016/j.ejsobi.2004.10.001

Kızılkaya R., Hepşen Ş. 2007. Microbiological properties in earthworm Lumbricus terrestris L. cast and surrounding soil amended with various organic wastes. Communication in Soil Science and Plant Analysis, 38: 2861-2876 http://dx.doi.org/10.1080/00103620701663107

Klikocka H., Narolski B., Klikocka O., Głowacka A., Juszczak D., Onuch J., Gaj R., Michałkiewicz G., Cybulska M., Stepaniuk S. 2012. The effect of soil tillage and nitrogen fertilization on microbiological parameters of soil on which spring triticale is grown. Polish Journal of Environmental Studies, 21 (6): 1675-1685

Kosteckas R., Marcinkevičienè A. 2009. The integrated evaluation of the influence of catch crops and manure on spring barley agrocenosis in organic farming. Agronomy Research, 1: 355-362

Li Y. T., Rouland C., Benedetti M., Li B., Pando A., Lavelle P., Dai J. 2009. Microbial biomass, enzyme and mineralization activity in relation to soil organic $\mathrm{C}, \mathrm{N}$ and $\mathrm{P}$ turnover influenced by acid metal stress. Soil Biology and Biochemistry, 41: 969-977 http://dx.doi.org/10.1016/j.soilbio.2009.01.021

Marinari S., Masciandaro G., Ceccanti B., Grego S. 2000. Influence of organic and mineral fertilizers on soil biological and physical properties. Bioresource Technology, 72 (1): 9-17 http://dx.doi.org/10.1016/S0960-8524(99)00094-2

Melero S., Ruiz Porras J. C. Herencia J. F. Madejón E. 2006. Chemical and biochemical properties in a silty loam soil under conventional and organic management. Soil and Tillage Research, 90: 162-170 http://dx.doi.org/10.1016/j.still.2005.08.016

Nannipieri P., Kandeler E., Ruggiero P. 2002. Enzyme activities and microbiological and biochemical processes in soil. Burns R. G., Dick R. P. (eds). Enzymes in the environment, activity, ecology and application, p. 1-33

Niu W-Q., Zang X., Jia, Z-X., Shao H. B. 2012. Effects of rhizosphere ventilation on soil enzyme activities of potter tomato under different soil water stress. Clean - Soil Air Water, 40 (3): 225-232 http://dx.doi.org/10.1002/clen.201100480

Okur N., Kayikçioglu H. H., Okur B., Delibacak S. 2008. Organic amendment based on tobacco waste compost and farmyard manure: influence on soil biological properties and butter-head lettuce yield. Turkish Journal of Agriculture and Forestry, 32: 91-99

Piotrowska A., Iamarino G., Rao M. A., Gianfreda L. 2006. Short-term effects of olive mill waste water (OMW) on chemical and biochemical properties of a semiarid Mediterranean soil. Soil Biology and Biochemistry, 38: 600-610 http://dx.doi.org/10.1016/j.soilbio.2005.06.012 
Ramirez K. S., Craine J. M., Fierer N. 2010. Nitrogen fertilization inhibits microbial respiration regardless of the form of nitrogen applied. Soil Biology and Biochemistry, 42: 2336$2338 \mathrm{http}: / / \mathrm{dx}$.doi.org/10.1016/j.soilbio.2010.08.032

Rodríguez-Kábana R., Truelove B. 1982. Effect of crop rotation and fertilization on catalase activity in a soil of the southeastern United State. Plant and Soil, 69 (1): 97-104 http://dx.doi.org/10.1007/BF02185708

Shah S. A., Shah S. M., Mohammad W., Shafi M., Nawaz H. 2009. N uptake and yield of wheat as influenced by integrate use of organic and mineral nitrogen. International Journal of Plant Production, 3 (3): 45-56

Statistical yearbook of agriculture. 2011. Central Statistical Office, Warsaw, Poland

Tejada M., Gonzalez J. L., García-Martínez A. M., Parrado J. 2008. Effects of different green manures on soil biological properties and maize yield. Bioresource Technology, 99: $1758-1767$ http://dx.doi.org/10.1016/j.biortech.2007.03.052

Thalmann A. 1968. Zur Methodik der Bestimmung der Dehydrodgenaseaktivität im Boden mittels
Triphenyltetrazoliumchlorid (TTC). Landwirtschaftliche Forschung, 21: 249-258 (in German)

Treseder K. 2008. Nitrogen additions and microbial biomass: a meta-analysis of ecosystem studies. Ecological Letters, 11 (10): 1111-1120 http://dx.doi.org/10.1111/j.1461-0248.2008.01230.x

Weisskopf L., Le Bayon R., Kohler F., Page V., Jossi M., Gobat J. M., Martinoia E., Aragano M. 2008. Spatio-temporal dynamics of bacterial communities associated with two plant species differing in organic acid secretion: a oneyear microcosm study on lupin and wheat. Soil Biology and Biochemistry, 40: 1771-1780 http://dx.doi.org/10.1016/j.soilbio.2008.02.018

Wilczewski E. 2013. The efficiency of nitrogen fertilization of spring wheat depending on seasonal rainfall. American Journal of Experimental Agriculture, 3 (3): 579-594

Włodarczyk T., Gliński J., Stępniewski W., Stępniewska Z., Brzezińska M., Kurá V. 2001. Aeration properties and enzyme activity on the example of Arenic Chernozem (Tišice). International Agrophysics, 15: 131-138

ISSN 1392-3196 / e-ISSN 2335-8947

Zemdirbyste-Agriculture, vol. 101, No. 2 (2014), p. 139-146

DOI 10.13080/z-a.2014.101.018

\title{
Fermentų veiklos pokyčiai dirvožemyje, priklausomai nuo žaliajai trąšai auginamų augalų ir tręšimo mineraliniu azotu
}

\author{
A. Piotrowska-Długosz, E. Wilczewski \\ Technologijos ir gyvybès mokslų universitetas, Lenkija
}

\section{Santrauka}

Mikroorganizmai turi didelès reikšmės dirvožemio maisto medžiagų apykaitai, todèl jie yra svarbus tyrimu objektas. Tyrimas buvo atliekamas trejus metus (nuo $2005 \mathrm{~m}$. rugpjūčio iki $2008 \mathrm{~m}$. rugpjūčio mèn.). Jo metu vertinta tarpinių augalų aliejinių ridikų (Raphanus sativus var. olifera L.) bei sėjamųjų žirnių (Pisum sativum L.) ir tręšimo neorganiniu azotu (N) $0,40,80,120$ bei $160 \mathrm{~kg} \mathrm{ha}^{-1}$ metai ${ }^{-1}$ itaka dirvožemio dehidrogenazès, katalazès ir fluoresceino diacetato hidrolizès veiklai pajaurejjusiame išplautžemyje (IDe). Tarpiniai augalai buvo pasèti rugpjūčio pradžioje ir užarti 2005, 2006 bei 2007 m. rudenị. Pagrindiniai augalai vasariniai kviečiai (Triticum aestivum L.) auginti 2006, 2007 ir 2008 m. Dirvožemio ėminiai imti du kartus per metus prieš vasarinių kviečių sejją (kovo arba balandžio mėn.) ir po derliaus nuėmimo (rugpjūčio mėn.). Tarpiniai augalai turèjo didelès įtakos dehidrogenazès ir katalazès veiklai visais tyrimų metais, o fluoresceino diacetato hidrolizès veiklai - tik $2007 \mathrm{~m}$. Didesnè dehidrogenazès ir fluoresceino diacetato hidrolizès įtaka buvo nustatyta laukeliuose su tarpiniais augalais, palyginus su kontroliniu variantu, ir tik kai kuriais atvejais - žirnių laukelyje, palyginus su ridikų. Dehidrogenazès ir katalazès veikla visuomet buvo intensyvesnė rugpjūčio mėnesį, palyginus su kovo arba balandžio. Tręšimas azotu dehidrogenazès ir fluoresceino diacetato hidrolizès veiklai turèjo įtakos tik $2007 \mathrm{~m}$., o katalazès - visą tyrimų laikotarpi (2006-2008 m.). Didžiausia katalazès veikla nustatyta patręšus 80 arba $120 \mathrm{~kg} \mathrm{ha}^{-1} \mathrm{metai}^{-1}$ azoto. Dirvožemio cheminèms savybėms (organinei angliai, suminiam azotui, $\mathrm{pH}_{\mathrm{KCC}}$ ) tarpiniai augalai ir tręšimas neorganiniu azotu didelès įtakos neturejjo. Tirti mikrobų biomasès rodikliai esmingai koreliavo su dirvožemio cheminèmis savybèmis.

Reikšminiai žodžiai: dehidrogenaze, išplautžemis, fluorescino diacetato hidrolizė, katalazè, tręšimas mineraliniu azotu, žalioji trąša. 